\title{
Autocrine/Paracrine Insulin-like Growth Factor Binding Protein-3 Acts as Pro-apoptotic Factor for Leydig cells in the Rat Testis
}

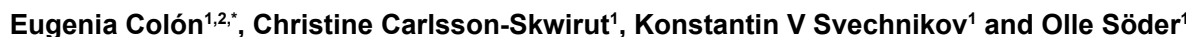

${ }^{1}$ Department of Woman and Child Health, Paediatric Endocrinology Unit, Astrid Lindgren Children's Hospital, Karolinska Institute and University Hospital, SE 17176 Stockholm, Sweden

${ }^{2}$ Department of Pathology and Cytology, Sodersjukhuset, Karolinska Institute and University Hospital, SE 11883 Stockholm, Sweden

\begin{abstract}
The secretory insulin-like growth factor-binding protein-3 (IGFBP-3) induces apoptosis via both insulin-like growth factor-I (IGF-I)-dependent and -independent mechanisms. Here, we have examined the effects of IGFBP-3 on Leydig cell apoptosis, proliferation and steroidogenesis. Immunohistochemical analysis of testes of rats at different ages revealed that IGFBP-3 is expressed first after 20 days of postnatal life and is present at a high level in the adult testis. In addition, Western blotting showed that the expression of IGFBP-3 in Leydig cells isolated from 60-day-old rats is higher than in 40-day-old animals. The rate of DNA synthesis (as assessed by incorporation of ${ }^{3} \mathrm{H}$-thymidine in vitro) in Leydig cells from 40-day-old rats is reduced by IGFBP-3, which also blocks the promotion of cell survival by IGF-I. Moreover, IGFBP-3 induces apoptosis in Leydig cells and, at the same time, attenuates the anti-apoptotic action of IGF-I. Furthermore, IGF-I stimulates secretion of IGFBP-3, -4 , and -2 by Leydig cells. The pro-inflammatory cytokine tumor necrosis factor- $\alpha$ induces apoptosis in these same cells and increases their secretion of IGFBP-3 and IGFBP-4.

These findings provide the first evidence that IGFBP-3 acts as a pro-apoptotic effector of Leydig cells and can also block the positive effect of IGF-I on cell survival. In addition, IGFBPs appear to modulate interactions between IGF-I and pro-inflammatory cytokines in the testis, suggesting possible participation of these proteins in processes such as testicular inflammation and cancer.
\end{abstract}

Keywords: IGFBP-3; IGFBP-2; PPP; Leydig cells; Steroidogenesis; IGF-I; IGF-IR

\section{Introduction}

Insulin-like growth factors (IGFs) are involved in cell metabolism, growth, differentiation, and survival (1) in most organs, including those of the reproductive axis [1-3]. The activities of these factors are regulated by a family of six high affinity-binding proteins (IGFBP-1-6), which determine IGF bioavailability in circulating fluids and the cellular environment $[1,4,5]$.

IGFBP-3 is the most abundant circulating IGF-binding protein and mediates IGF independent actions on cell survival and apoptosis [6,7]. In the testis, IGFs and IGFBPs are localized in the same cells that express LH and FSH receptors [8-10]. IGFBP-2 and -3 are the most abundant IGFBPs in this organ [9] and large amounts of IGFBP-3 are produced by Sertoli and Leydig cells $[9,11]$. Both FSH and (Bu)2cAMP markedly lower IGFBP-3 levels in Sertoli cells [11] and this binding protein can either inhibit or enhance the effects on Leydig cells steroidogenesis depending on the surrounding conditions $[9,12]$.

The involvement of IGFBP-3 in steroidogenesis, development, and tumor growth in the testis is poorly understood. Previous investigations have revealed that IGFBP-3, -4 , and -2 are predominantly expressed by Leydig cells [9]. It has been proposed that IGFBP-3 also potentiates the inhibitory effects of cytokines on steroidogenesis $[9,12]$. Both IGFBP-3 and -4 have been reported to be down-regulated in testicular seminomas [13], allowing more rapid tumor growth.

How the apoptotic effects of IGFBP-3 are mediated in the testis is largely unclear. It was described previously that IGFBP-3 can induce apoptosis via an intrinsic apoptotic pathway [14]. Apoptotic stimuli lead to an increase in the permeability of the outer mitochondrial membrane and promote the release of cytochrome $\mathrm{c}$ into the cytosol. Cytochrome $c$ binds to apoptotic protease-activating factor- 1 and caspase-9, promoting the activation of caspase-3 [15]. Members of the
Bcl-2 family have been shown to influence this process [16]

Apoptosis can also be induced via an extrinsic pathway that involves ligand-mediated activation of death receptors, such as the TNF receptor 1 (TNFR1). Upon binding of TNFa to the TNFR1, an intracellular death effectors complex is formed, consisting of adaptor molecules, such as Fas-associated death domain protein and an inactive precursor form of caspase-8 [17]. Formation of this complex leads to cleavage of caspase- 8 into active subunits and the subsequent proteolysis of downstream substrates. Activation of the transcription factor nuclear factor-kB (NFkB) by nuclear translocation elicits a potent survival signal and blocks this death receptor-mediated apoptotic pathway [18].

Following secretion, IGFBP-3 is well known to inhibit growth via both IGF-I-dependent and -independent pathways [6,7]. Such effects have been observed with different types of cells, including prostate and breast cancer cells $[7,19,20]$. The possible independent effects of IGFBP-3 on Leydig cell function have not been studied.

IGFBP-3 levels are regulated by multiple factors, including cytokines. We and others have demonstrated the relation between cytokines and binding proteins in Leydig cells $[8,9,21]$. The inhibitory effects of IL-1 $\beta$ and IL-1 $\alpha$ on Leydig cell steroidogenesis is partially

*Corresponding author: Colón E, Department of Pathology and Cytology, Sodersjukhuset, Karolinska Institute and University Hospital, SE 11883 Stockholm, Sweden, Tel: +46 8 6164512; E-mail: eugenia.colon@ki.se

Received May 20, 2016; Accepted June 04, 2016; Published June 09, 2016

Citation: Colón E, Skwirut CC, Svechnikov KV, Söder O (2016) Autocrine/ Paracrine Insulin-like Growth Factor Binding Protein-3 Acts as Pro-apoptotic Factor for Leydig cells in the Rat Testis. J Steroids Horm Sci 7: 174. doi:10.4172/21577536.1000174

Copyright: ( 2016 Colón E, et al. This is an open-access article distributed unde the terms of the Creative Commons Attribution License, which permits unrestricted use, distribution, and reproduction in any medium, provided the original author and source are credited. 
mediated by the stimulation of IGFBP-2 and -3 , suggesting that these cytokines utilize common pathways. Cytokines are generated under both normal and pathological circumstances and have been implicated in the pathogenesis of diseases such as inflammation and cancer in the testis [21-23]. Previous experiments from our group have demonstrated the constitutive production of both IL- $1 \alpha$ and IL-18 by the testis [23,24]. IL-18 is a defense factor in the male gonad and IL-1a can stimulate or inhibit steroidogenesis depending on the surrounding conditions $[12,21]$.

The testis is a site of IGF-I biosynthesis and action; high levels of IGFBP-3 are expressed in normal testis $[8,25]$. IGF-I mRNA and protein, as well as specific IGF-I receptors, are present in the testis and have been localized in Leydig, peritubular and germ cells [26]. Testicular levels of IGF-I peak during the fourth week postpartum at the beginning of the pubertal rise in testosterone secretion [26]. Since IGFBP-3 regulates IGF-I bioavailability and IGF-I is involved in the processes of differentiation, steroidogenesis, and apoptosis in Leydig cells, we studied the modulation of IGFBPs on the effects of IGF-I at the time of IGF-I peak expression in the testis.

Recently, the independent actions of IGFBP-3 on apoptosis have been described in other model systems. At present, little is known about the independent actions of IGFBP-3 and its interactions with pro-inflammatory cytokines in the testis. In this study, we investigated the influence of IGFBP-3 on Leydig cell function and apoptosis, as well as the regulation of the secretion of this binding protein by IGF-I and certain pro-inflammatory cytokines.

\section{Materials and Methods}

\section{Reagents}

Dulbecco's Modified Eagle's Medium (DMEM)-Ham's nutrient mixture F-12, Modified Eagle's Medium (MEM), Hank's Balanced Salts Solution (HBSS) without $\mathrm{Ca}^{2+}$ or $\mathrm{Mg}^{2+}$, and penicillin and streptomycin were purchased from Invitrogen (Life Technologies, Inc. Paisley, UK). Bovine serum albumin (BSA) (fraction V), Percoll, HEPES and collagenase type I (Sigma-Aldrich St. Louis, MO) were used to isolate Leydig cells, which were subsequently treated with recombinant rat IGF-I, IGF-II, IGFBP-3, (GroPep Limited, Adelaide, Australia) IL-1 $\beta$, IL18 and/or TNFa (R\&D Systems, Abingdon, UK). The Cell Proliferation Reagent WST-1 (Roche Diagnostics, Penzberg, Germany), was employed to assess cell viability and the Analysis of DNA Fragmentation by Cell Death Detection ELISA ${ }^{\text {plus }}$ (Roche Diagnostics, Meylan, France), kit to monitor apoptosis.

Western blotting was performed with anti- $\alpha$-tubulin (Santa Cruz Biotechnology Inc., CA, USA), anti IGFBP-3 (GroPep Limited, Adelaide, Australia), and anti-caspase 3 (Santa Cruz Biotechnology Inc., CA, USA) antibodies. The cyclolignan PPP (picropodophyllin); (a kind gift from Dr Olle Larsson and Dr Magnus Axelson) was synthesized and recrystallized to obtain a final purity of $99.7 \%$ and dissolved physiological in saline $(5 \mu \mathrm{M})$ or DMSO $(0.5 \mathrm{mM})$ prior to addition to the medium of cell cultures [27].

\section{Experimental animals}

Testes and Leydig cells were obtained from 10-, 20-, 40- and 60-day-old male Sprague-Dawley rats (B\&K Laboratories, Sollentuna, Sweden), employing five animals in each age group, as described below. These animals were provided with a standard pellet diet and water ad libitum. All animal experiments were conducted in accordance with institutional guidelines and approved in advance by the local ethics committee for animal experimentation (N 218/05).

\section{Immunocytochemistry}

For each age group five testes, one from each animal, were stained with primary antibodies directed towards IGFBP-3 (see above) together with the HRP-Streptavidin complex (Rabbit Immunocruz staining system, Santa Cruz Biotechnology, Inc., USA), in accordance with the manufacturer's instructions. In brief, tissue sections were deparaffinized and then placed in Tris-buffered saline containing 0.05\% Tween-20 ( $\mathrm{pH}$ 7.6) (TBS/T) for $5 \mathrm{~min}$. Thereafter, the antigen was retrieved by placing the tissues in $10 \mathrm{mM}$ citrate buffer, $\mathrm{pH}$ 6.0, after which endogenous peroxidase activity was blocked by incubation with $3 \%$ $\mathrm{H}_{2} \mathrm{O}_{2}$ for $30 \mathrm{~min}$. Subsequently, the sections were incubated overnight at $4^{\circ} \mathrm{C}$ with anti-IGFBP-3 (at a dilution of 1:50), followed by sequential exposure for 1 hour each to a biotinylated secondary antibody and a peroxidase-conjugated streptavidin complex. Thereafter, staining with 3,3-diaminobenzidine tetrahydrochloride (Peroxidase Substrate Kit, SK-4100, Vector Laboratories, Inc.) resulted in a brown color localized in the cytoplasm and clearly distinguishable from the unstained background. The specificity of the antibody towards IGFBP-3 was confirmed by incubation of parallel sections with non-immune rabbit IgG at the same dilution (negative control). All sections were then counterstained with Mayer's hematoxylin, dehydrated and mounted under a coverslip with resin (Permount, SP15-100, Fisher Scientific Co. USA).

Finally, 10 separated fields in each of three non-adjacent sections from each testis were examined for staining employing a Nikon Eclipse E800 microscope (40-fold magnification; Nikon, Inc., Melville, NY) equipped with a SPOT RT digital camera (Diagnostic Instruments, Inc., Nikon, Inc., Melville, NY) and interfaced with a computer.

\section{Isolation and culture of Leydig cells}

Leydig cells from rats 40 days (immature Leydig cells) and older (60 days, adult Leydig cells) were prepared according to the procedure developed by Klinefelter et al. [28], as described earlier [2,29]. The corresponding cells from 10-day-old rats (progenitor Leydig cells) were obtained as described by Khan [30]. The purity of these Leydig cell preparations was $90 \%$, as demonstrated by specific histochemical staining for 3-hydroxysteroid dehydrogenase [31], 11ßhydroxysteroid dehydrogenase [32], anti-cytokeratin pan antibody for Sertoli cells [33], together with ED2 staining for macrophages [34]. Examination of Trypan blue exclusion revealed that cell viability was routinely greater than $96 \%$.

Subsequently, $1.5 \times 10^{4}$ cells in a total volume of $200 \mu \mathrm{l}$ were usually plated in each individual well of 96 -well plates (Falcon, USA) and then incubated for 24 hours at $34^{\circ} \mathrm{C}$. At this point, the culture medium was replaced by fresh medium containing IGFBP-3 (1-100 ng/ml) and/or IGF-I (10-100 ng/ml) [21] and thereafter incubated for an additional 24 hours. In the case of Western ligand blotting $2 \times 10^{6}$ cells were incubated in each well of 6-well plates (Falcon, USA) for 24 hours, following which the culture medium was replaced by fresh medium with or without IGF-I (10 ng/ml), IGF-II (10 ng/ml) [21], IL-1 $\beta$ [29], IL-18 (100 ng/ml) [23], TNFa (10 ng/ml) and/or PPP (100 nmol/L) [35] and incubated for an additional $24 \mathrm{~h}$.

\section{Quantification of DNA synthesis by Leydig cells in vitro}

After culturing of 96-well plates as described above, Leydig cells isolated from 10-40-days-old rats were labeled for the final 4 hours of culture with ${ }^{3} \mathrm{H}$-thymidine $(1 \mu \mathrm{Ci}$ per well; Amersham Pharmacia 
Biotech, Little Chalfont, UK) and the radioactivity incorporated (cpm) was subsequently determined using a Beckman scintillation spectrometer. In each individual experiment triplicate or quadruplicate cell cultures were subjected to each treatment and three independent experiments were performed.

\section{Determination of the number of viable Leydig cells in cultures}

The numbers of viable Leydig cells in each culture were determined employing the WST-1 procedure (Roche Diagnostics $\mathrm{GmbH}$, Mannheim, Germany), as described previously [2]. Accordingly, following treatment of Leydig cells in culture with IGFBP-3 (1-100 ng/ $\mathrm{ml})$ and /or IGF-I (100 ng/ml), $100 \mu \mathrm{l}$ serum-free DMEM and $10 \mu \mathrm{l}$ WST- 1 were added to each well and the increase in absorption at 450 $\mathrm{nm}$ monitored for $60 \mathrm{~min}$.

\section{Determination of Leydig cell apoptosis in vitro}

The extent of apoptosis occurring in cultured Leydig cells was assessed with an ELISA kit designed for both qualitative and quantitative photometric determination of cytoplasmic levels of histone-associated DNA fragments. In this case Leydig cells $\left(1.5 \times 10^{4}\right.$ per well) were cultured on 96-well plates for 24 hours, and then treated with IGFBP-3 (1-100 ng/ml), IGF-I (10-100 ng/ml) and/or TNFa (10 $\mathrm{ng} / \mathrm{ml}$ ) for an additional 24 hours. For treatments involving both IGF-I and TNFa, IGF-I was added $30 \mathrm{~min}$ prior to the cytokine. Following incubation, attached cells were harvested and centrifuged at $1500 \mathrm{rpm}$ for $6 \mathrm{~min}$, after which the resulting pellets were subjected to the ELISA procedure in accordance with the manufacturer's instructions. The level of cytoplasmic nucleosomes in treated cells was calculated as a percentage of the corresponding value for untreated cells.

\section{Western blotting}

The levels of the IGFBP-3 and caspase- 3 were analyzed by PAGE/ Western blotting. For this purpose cells were washed twice with PBS and then disrupted by sonication in a lysis buffer. Protein transfer and blocking was performed as described previously [21]. The PVDF membrane was stained with $5 \%$ Ponceau S for 5 minutes in order to confirm equal transfer of different proteins. In all cases $\alpha$-tubulin was used as an internal control for loading.

Incubation with antibodies was performed in accordance with the manufacturer's specifications and, after additional washing; bound antibody was labeled with donkey anti-rabbit or sheep anti-mouse IgG secondary antibodies conjugated with horseradish peroxidase (Amersham Pharmacia Biotech). Finally, for detection by enhanced chemiluminescence these blots were incubated with ECL Plus Western blotting agent and then exposed to ECL Hyperfilm (Amersham Pharmacia Biotech). In accordance with the manufacturer's instructions stripping and reanalysis of the membranes were also accomplished.

\section{Western ligand blotting}

IGFBPs were examined by Western ligand blotting in the manner as originally described by Hossenlopp et al. (36) with minor modifications. Conditioned media from primary cultures of Leydig cells incubated in the absence or presence of IGF-I $(10 \mathrm{ng} / \mathrm{ml})$, IGF-II $(10 \mathrm{ng} / \mathrm{ml})$, IL$1 \beta(10 \mathrm{ng} / \mathrm{ml}), \mathrm{IL}-18(100 \mathrm{ng} / \mathrm{ml})$ and/or TNF $\alpha(10 \mathrm{ng} / \mathrm{ml})$ and/or $100 \mathrm{nmol} / \mathrm{L}$ PPP for 24 hours were collected for this purpose. When present, PPP was added to the culture medium 1 hour prior to the addition of IGF-I.

Briefly, normal rat serum ( $5 \mu \mathrm{l})$, recombinant human IGFBP-2 (40 $\mathrm{ng}$ ), or an aliquot of the medium from Leydig cell cultures $(100 \mu \mathrm{l})$ was diluted with non-reducing sample buffer containing sodium dodecyl sulfate for separation by SDS-PAGE ( $12 \%$ gels). The resulting bands were electroblotted onto nitrocellulose filters (with a pore size of $0.45 \mu \mathrm{m}$ ) in a Hoefer Semi-Dry Transphor unit at $200 \mathrm{~mA}$ (Amersham Biosciences) during 1 hour. Thereafter, the filters were treated sequentially with $0.1 \%$ Tween 20 in Tris-buffered saline (pH 7.6) (TBS-T) and 1\% BSA in TBS-T, and subsequently probed with 125I-labeled IGF-I dissolved in TBS-T containing $1 \%$ BSA $\left(2 \times 10^{6} \mathrm{cpm} / 50 \mathrm{ml}\right)$. Next, the filters were washed with TBS-T, dried, and subjected to autoradiography. Finally, each band was analyzed by densitometry and its level expressed as the fold-increase in relationship to the corresponding control band.

\section{Determination of androgen production}

Conditioned media collected from the various cell cultures described above were stored at $-20^{\circ} \mathrm{C}$ prior to being assayed for testosterone and $5 \alpha$-androstane- $3 \alpha, 17 \beta$-diol, the predominant androgens synthesized by immature Leydig cells. Testosterone was determined employing a Coat-a-Count RIA kit, with a cross-reactivity for $5 \alpha$-androstane- $3 \alpha, 17 \beta$-diol of $0.4 \%$ (Diagnostic Products Corp., Los Angeles, CA), in accordance with the manufacturer's instructions. $5 \alpha$-androstane- $3 \alpha, 17 \beta$-diol was quantitated by RIA using specific antiserum (Cosmo Bio Co. LTD., Tokyo, Japan) and radiolabeled 5 $\alpha-[9$, $\left.11,-{ }^{3} \mathrm{H}(\mathrm{N})\right]$ androstane- $3 \alpha, 17 \beta-$ diol (specificity radio activity $=40 \mathrm{Ci} /$ mmol; NEN Life Science Products, Boston, MA) with a cross-reactivity for testosterone of $0.2 \%$.

\section{Statistical analyses}

All data are presented as mean values \pm SD. Comparison of androgen levels (i.e., the sum of the levels of $5 \alpha$-androstane- $3 \alpha, 17 \beta$-diol and testosterone) was performed using a one-way repeated measures analysis of variance ANOVA, together with Tukey's post-hoc test for pair-wise comparisons. Rates of cell proliferation, the degrees of cell survival and death, and the values obtained by western and western ligand blotting were compared utilizing one-way repeated measures analysis of variance ANOVA, employing the Holm-Sidak procedure for all pair-wise multiple comparisons. In all cases a $\mathrm{p}$ value of $<0.05$ was considered to be statistically significant.

\section{Results}

\section{Western blotting analysis and cellular distribution of IGFBP-3 expression during postnatal testicular development}

Immunohistochemical analysis of the testis of rats at different ages revealed that staining for IGFBP-3 increased from 10-60 days of postnatal age (Figures $1 \mathrm{~A}-1 \mathrm{~K}$ ). On postnatal day 10 no expression of IGFBP-3 was found (Figure 1A), at 20 days of age, Leydig cells (LC) stained positively for IGFBP-3 (Figure 1C); at 60 days of age Leydig cells (LC) also stained positively (Figures 1H-1J). These findings are in good agreement with the results of Western blotting (Figure 2), which revealed that expression of IGFBP-3 by cultures of Leydig cells isolated from 60-day-old rat testis was 3.2 -fold higher than in the case of 20-day-old testis and 2.3-fold higher than that of testis of 40-day-old rats (Figure 2).

\section{The influence of IGFBP-3 on the survival and DNA synthesis of rat Leydig cells in culture}

We studied the possible direct and indirect action of IGFBP-3 on proliferation and viability in progenitor Leydig cells and immature Leydig cells. We wanted to study the relation between the rising of IGF-I and the levels of IGFBP-3 at this time of development. The effect 
Citation: Colón E, Skwirut CC, Svechnikov KV, Söder O (2016) Autocrine/Paracrine Insulin-like Growth Factor Binding Protein-3 Acts as Pro-apoptotic Factor for Leydig cells in the Rat Testis. J Steroids Horm Sci 7: 174. doi:10.4172/2157-7536.1000174
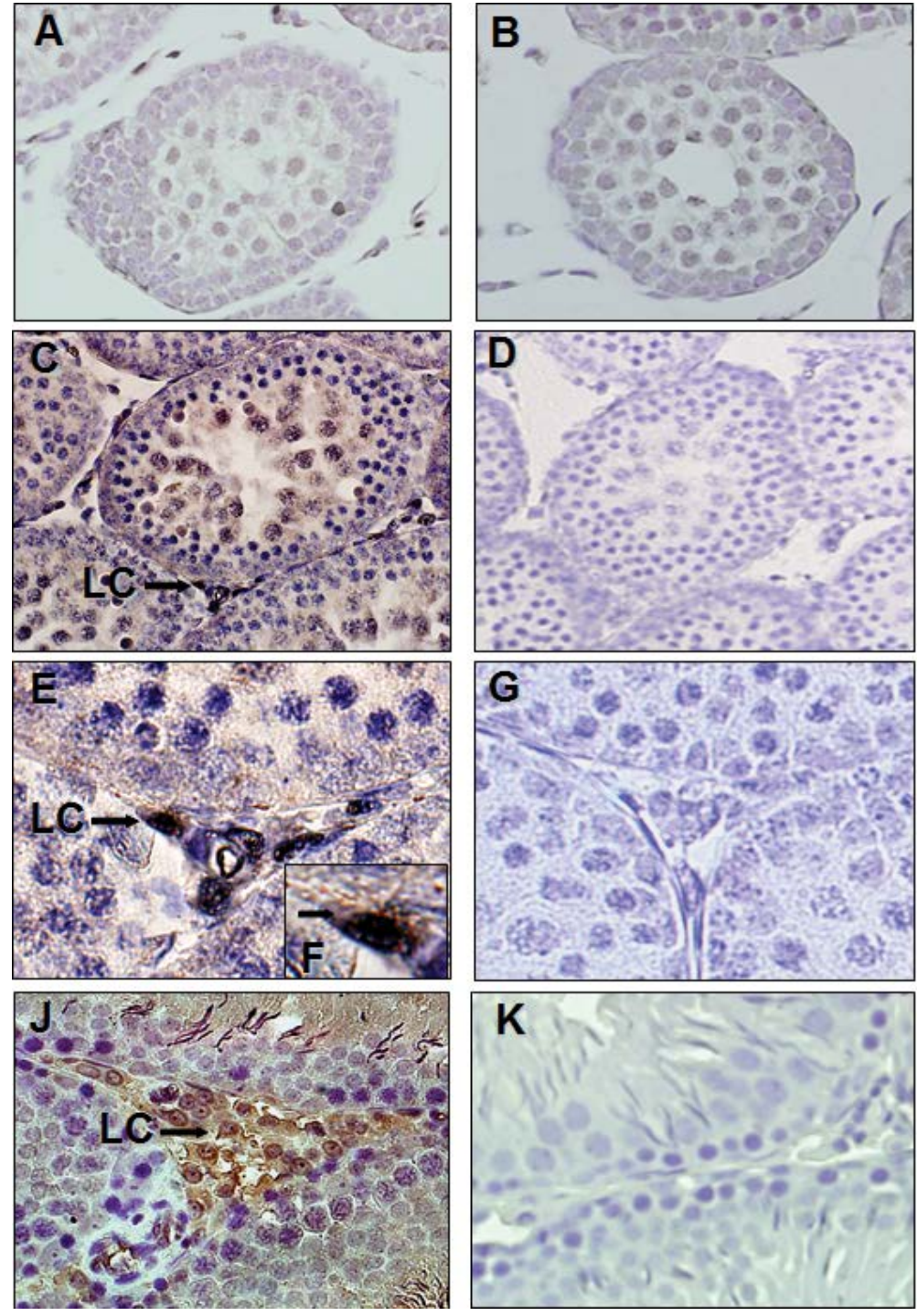

Figure 1: Immunohistochemical detection of IGFBP-3 in the testis of rats of different ages. (A) The testis of the 10-day-old rat demonstrated no staining for IGFBP-3. (B) Negative control for (A), involving incubation with non-immune rabbit IgG at the same dilution as the antibody (see the Materials and Methods). (C) In the testis of the 20-day-old rat, Leydig cells (LC) (indicated by arrows) in the interstitial compartment expressed IGFBP-3. (D) Negative control for (C), performed as in (B). (E, F) The interstitial compartment of testes from 20-day-old rats, arrows indicate Leydig cells (LC). (G) Negative control for E. (J) Two-fold higher magnification of interstitial compartment of the testis of adult (60-day-old) rats with arrows indicating Leydig cells staining positively for IGFBP-3. (K) Negative control for (J), performed as in (B). Levels of magnification: A, B, E, G, J, K: 60X; C, D: 40X; F: 100X.

of IGFBP-3 on the proliferation and viability of cultured Leydig cells isolated from 10 and 40-day-old rats were measured. DNA synthesis by untreated Leydig cells isolated from 10-day-old rats, declined spontaneously during the 48 -hour culture period (Figure $3 \mathrm{~A}$ ). In the presence of IGF-I, the initial rate of this synthesis was maintained, while IGFBP-3 (1-100 ng/ml), either alone or in combination with IGF-I had no effect on this parameter (Figure 3A). IGFBP-3 had also no effect on cell viability at this age (Figure 3B).

In the case of cultured Leydig cells from 40-day-old rats, IGF-I $(100 \mathrm{ng} / \mathrm{ml})$ also prevented the spontaneous decline in the rate of DNA synthesis (as assessed by incorporation of $\left[{ }^{3} \mathrm{H}\right] \mathrm{TdR}$ into DNA between hours 44 and 48 of incubation), but in these cultures IGFBP- 3 reduced the rate of DNA synthesis (at a concentration of $100 \mathrm{ng} / \mathrm{ml}$ ) and blocked the action of IGF-I (at 10-100 ng/ml) (Figure 3C).
The viability of cultures of Leydig cells isolated from 40-day-old rats (as assessed by the WST-1 procedure) mirrored the incorporation of $\left[{ }^{3} \mathrm{H}\right] \mathrm{TdR}$ (Figure 3D). Thus, with no treatment, the number of viable cells remaining following 48 hours of incubation was 35\% lower than the initial number and IGF-I prevented this loss of viable cells (Figure 3D). IGFBP-3 $(100 \mathrm{ng} / \mathrm{ml})$ inhibited this promotion of survival by IGF-I.

To understand the kinetics of the action of IGFBP-3 on Leydig cell viability we tested the action of IGFBP- 3 at different time points ( 0 . $12,24 \mathrm{~h}$ ). IGFBP-3 was able to decrease the survival effect of IGF-I on Leydig cells (Figure 4A).

To clarify the action of IGFBP-3 in Leydig cells at this stage of development (immature Leydig cells) we studied the possible apoptotic effect. IGFBP-3 enhanced apoptosis, as well as attenuating the reduction 
IGFBP-3 (42-45 kDa) $\alpha$-tubulin $(50 \mathrm{kDa})$

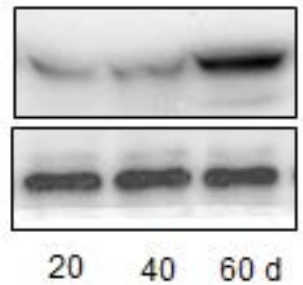

OD $25 \pm 236 \pm 8^{*} 82 \pm 4^{*}$

Figure 2: The levels of IGFBP-3 in Leydig cells isolated from 20-, 40- and 60-day-old rats (as determined by Western blotting). Blotting was performed employing the anti-IGFBP-3 antibody and a-tubulin as an internal control for constant loading. Representative experiment: below, the density of the IGFBP-3 band relative to that of $\alpha$-tubulin (mean \pm SD; $n=3$ ) is shown, *: $\mathrm{p}<0.05$ in comparison to the corresponding value for 20 -day-old rats.

in apoptosis caused by IGF-I (Figure 4B). To elucidate the mechanism of action of IGFBP-3 we tested the activation of caspase- 3 at different time points. The result showed that exposure to IGFBP-3 $(100 \mathrm{ng} / \mathrm{ml})$ during $24 \mathrm{~h}$ is associated with cleavage of caspase- 3 into active fragments $(20$ and $17 \mathrm{kDa}$ ) (Figure 4C)

\section{Relation between steroidogenesis and secretion of IGFBPs}

Since the main function of Leydig cells is the production of androgens we tested the action of IGFBP- 3 on steroidogenesis and the influence of IGFBP-3 on IGF-I stimulated Leydig cells. In culture of Leydig cells isolated from 40-day-old rats, IGFBP-3 itself decreased the total level of androgens present and furthermore attenuated the stimulation of steroidogenesis by IGF-I (Figure 5A).

Subsequently, we stimulated Leydig cells with IGF-I to investigate the effect of this peptide on IGFBPs secretion. The pattern of secretion of the IGFBPs by untreated and treated Leydig cells was examined employing Western ligand blotting with radioactive IGF-I as a probe. This procedure revealed a double band with an apparent molecular weight of 42-45 kilo Dalton $(\mathrm{kDa})$, another band at $30 \mathrm{kDa}$ and an additional band at $24 \mathrm{kDa}$, corresponding to IGFBP-3, IGFBP-2 and IGFBP-4 respectively, as demonstrated by previous investigations [21]. The finding demonstrated that the enhanced production of androgens by IGF-I (Figure $5 \mathrm{~A}$ ) was associated with more extensive secretion of IGFBP-2 and IGFBP-3 (Figure 5B).

To investigate the possible role played by IGF-IR in IGFBPs secretion, we treated cells with IGF-I or IGF-II in the absence or presence of a selective inhibitor of IGF-IR, the cyclolignan PPP. IGFII was used in this context since it acts as an IGF-IR agonist at high concentration, thus serving as a positive control to IGF-I action. Pretreatment with PPP [27], prevented the enhanced secretion of all investigated IGFBPs induced by IGF-I or IGF-II (Figure 5C).

\section{Effects of IL-1 $\beta$, IL-18 and TNFa on secretion of IGFBPs by Leydig cells}

Previously it has been demonstrated that IL- $1 \beta$ and TNFa can modulate the expression of IGFBPs in the testis. To further characterize the regulation of binding protein secretion by cytokines and growth factors in Leydig cells, the effects of IL- $1 \beta$, IL-18 and TNF $\alpha$ alone were examined.
As shown in Figure 6A, IL-1 $\beta$ by itself stimulated the secretion of IGFBP- 3 and diminished the level of IGFBP-2 in the medium of these same cultures. IL-18 alone stimulated the secretion of IGFBP- 3 and IGFBP-2 (Figure 6A).

TNFa stimulated the secretion of IGFBP- 3 and IGFBP-4 by Leydig cells from 40-day-old-rats (Figure 6B). Furthermore, the induction of apoptosis in these Leydig cells by TNFa could be substantially prevented by pre-treatment with IGF-I (Figure 6C).

\section{Discussion}

The involvement of IGFBP-3 in steroidogenesis, development and tumor growth in the testis is poorly understood. In the present investigation we demonstrated that IGFBP-3 is expressed in a developmental fashion in the rat testis and for the first time, that IGFBP-3 itself induces apoptosis in Leydig cells by activating caspase- 3 in a manner dependent on the stage of development. Furthermore, this binding protein blocks the promotion by IGF-I of the survival of rat Leydig cells from 40-days-old rats in cultures. Apparently, expression of IGFBP-3 plays an important role in the development of the testis and may influence the numbers of cells present in the mature testis.

IGFBP-3 induces apoptosis via both IGF-dependent andindependent mechanisms [6]. Interestingly, we found that IGFBP-3 does not induce apoptosis in Leydig cells isolated from 10-days-old rats (progenitor Leydig cells) but clearly induce apoptosis in Leydig cells isolated from 40-days-old rats (immature Leydig cells). These results suggest a developmental action of IGFBP-3 that may be explained by the pattern of expression of IGFBP-3, the possible developmental expression of the IGFBP-3 receptor or a relationship with the expression of IGF-IR in Leydig cells [36].

IGFBP-3 may inhibit cell growth by induction of apoptosis either indirectly, by sequestrating insulin-like growth factors away from the insulin-like growth factor receptor, or directly via a putative IGFBP-3 receptor and/or translocation to the nucleus. At present, the identity of IGFBP-3 receptor is not well established [19,37,38].

Previous data demonstrate that IGFBP-3 can exert its actions on target cells in several ways: (a) inducing apoptosis; (b) regulating the cell cycle; and (c) possible cross-talk with major signal transduction pathways. Possible mechanisms for intrinsic apoptotic pathway of IGFBP-3 involve, in part, increasing of the ratio of pro-apoptotic (Bax and $\mathrm{Bad}$ ) to anti-apoptotic (Bcl-2 and $\mathrm{Bcl}-\mathrm{XL})$ proteins and rising of caspase- 3 activity [39]. Our results suggest that IGFBP-3 may induce the activation of caspase- 3 at $12 \mathrm{~h}$ or earlier after start of incubation and that the increased activity at this time point was related with lower viability.

The testis is a site of IGF-I production and action [25]. Testicular levels of IGF-I peak during the fourth week postpartum, at the start of the pubertal rise in testosterone secretion [25]. The expression of IGFBP-3 in Leydig cells is high at this point of development and it is known that IGFBP-3 serves as an important regulator of IGF-I activity. We suggest that the action of IGF-I in differentiation, proliferation and apoptosis in the testis is modulated by IGFBP-3 and maybe also by other IGFBPs, and that this modulation is necessary for the proper function of IGF-I. Furthermore, we observed here that pre-treatment with PPP, a selective inhibitor of IGF-IR, attenuated the stimulation by IGF-I and IGF-II on IGFBPs secretion by Leydig cells, suggesting that IGF-IR plays a key role in this process.

Postnatally, the proliferative capacity of the Leydig cell lineage 

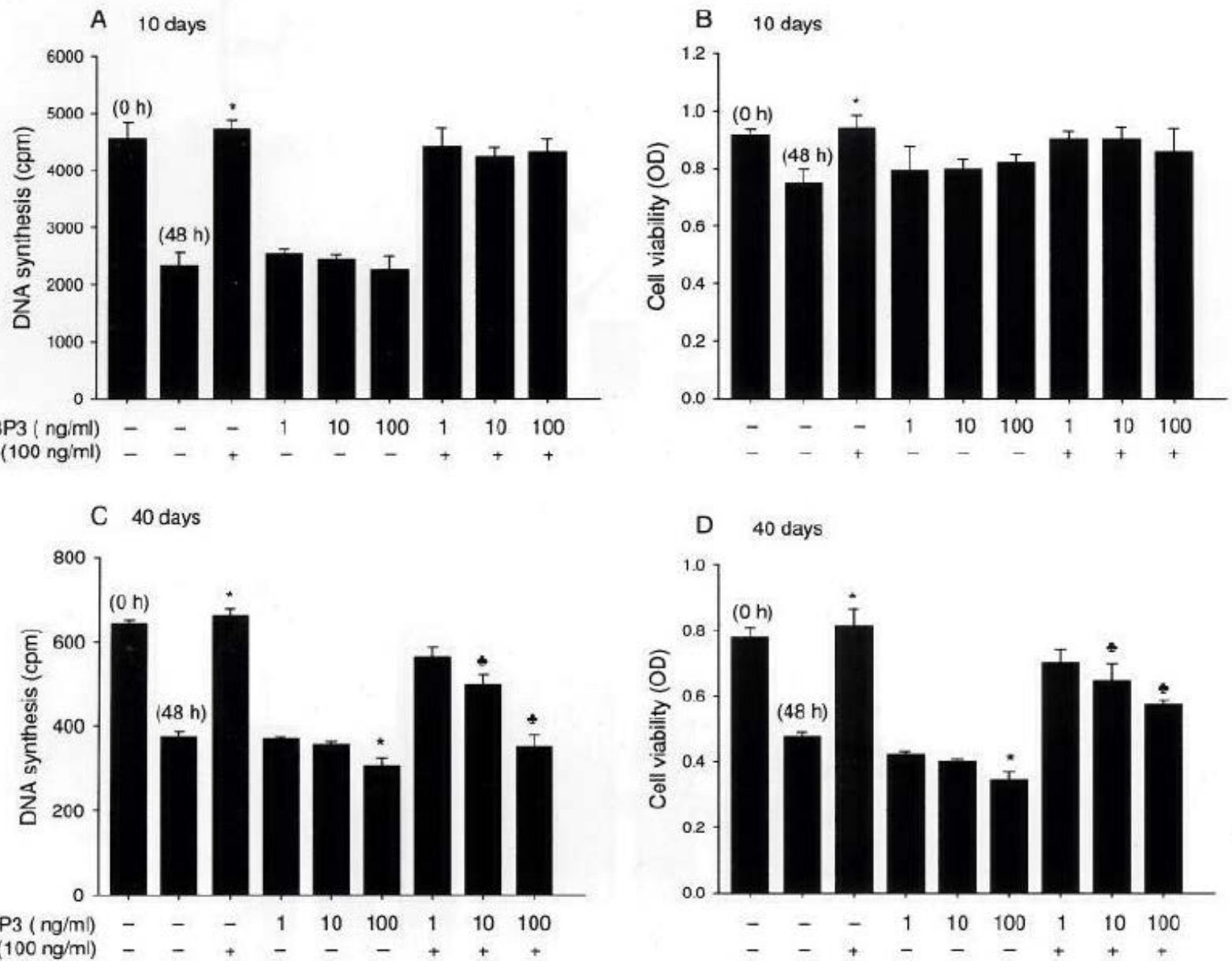

Figure 3: Effects of IGFBP-3 and/or IGF-I on DNA synthesis (A, C), and cell viability (B, D) in cultures of Leydig cells isolated from 10- and 40-day-old rats. Leydig cells were isolated, cultured and treated as described in the Materials and Methods. All values shown represent means \pm SD for three independent experiments. (A, 10d) $(C, 40 \mathrm{~d})$ Incorporation of ${ }^{3} \mathrm{H}$-thymidine by untreated cells at the beginning of the culture period i.e., between 0 and 4 hours of culture, and by both untreated and treated cells between hours 44 and 48 of incubation ( $48 \mathrm{~h}$ ). ${ }^{*}: \mathrm{p}<0.05$ compared to the 48 -hour value for untreated control cells. s: $p<0.05$ compared to the 48-hour value for cells exposed to IGF-I.

$(B, 10 d)(D, 40 d)$ The numbers of viable cells as assessed employing the WST-1 procedure. Following treatment (see above), $10 \mu \mathrm{l}$ of the WST-1 reagent was added to each well (containing $1.5 \times 10^{4}$ cells); the incubation continued for an additional 60 minutes at $37^{\circ} \mathrm{C}$; and finally, the absorption of the culture medium at $450 \mathrm{~nm}$ was determined. OD=optical density units. * $\mathrm{p}<0.05$ compared to the 48 -hour value for untreated control cells, $\$$ : $p<0.05$ compared to the 48-hour value for cells exposed to IGF-I.

is suppressed during the transition from progenitor Leydig cells to immature Leydig cells, a process that seems to be under genetic control [40]. The developmental expression of IGFBP-3 also suggests that this protein is involved in the process of development and perhaps in the reduced capacity of proliferation. IGFBP-3 may also be involved in the regulation of androgen production. Previously, it has been demonstrated that IGFBP-3 inhibits stimulation of Leydig cell steroidogenesis by IGF-I and mediates the inhibitory action of IL$1 \beta$ and TNFa on steroidogenesis $[8,12]$. These findings are strongly supported by the present data. In order to investigate the function of IGFBP-3 under inflammatory conditions and the possible action on the extrinsic pathway of apoptosis in the testis, we studied the effect of TNFa on IGFBPs expression and apoptosis. Our data suggest that a rise in IGFBP-3 is involved in the apoptotic action of TNFa in Leydig cells. Additionally, the apoptotic effect of TNFa could be prevented by pre-treatment with IGF-I, suggesting a cross-talk between the pathways involved in the actions of both of these substances. The protective effect of IGF-I on TNFa induced apoptosis has also been observed in other model systems, including the neuronal SH-SY5Y cell line $[41,42]$. This suggests that IGFBP-3 may also play a role in mediating extrinsic apoptotic pathways in cells that are sensitive to the actions of TNF- $\alpha$.

Pro-inflammatory cytokines are apparently involved in certain pathological process in the testis. For instance, local levels of TNFa and IL- $1 \beta$ are elevated, following ischemia/reperfusion of this organ, suggesting that these cytokines are early mediators of ischemia/ reperfusion-induced testicular injury [22]. There are clear differences in the individual effects of these cytokines on secretion of IGFBPs by Leydig cells, indicating that they have different roles to play. Previously, TNFa was found to attenuate the stimulatory action of IGF-I on the level of FSH receptors on Sertoli cells [43] demonstrating that IGF-I plays a role in the functioning of these cells as well. Our findings suggest the existence of antagonistic interactions between TNFa and IGF-I with respect to their effects. The present findings clearly indicate that IGFBPs 
Citation: Colón E, Skwirut CC, Svechnikov KV, Söder O (2016) Autocrine/Paracrine Insulin-like Growth Factor Binding Protein-3 Acts as Pro-apoptotic Factor for Leydig cells in the Rat Testis. J Steroids Horm Sci 7: 174. doi:10.4172/2157-7536.1000174
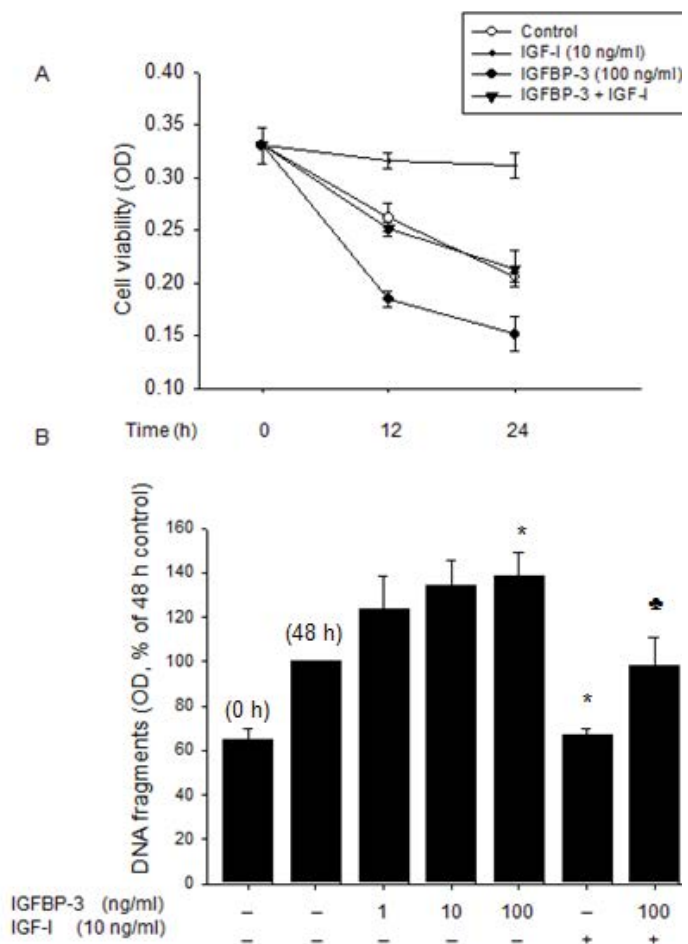

C

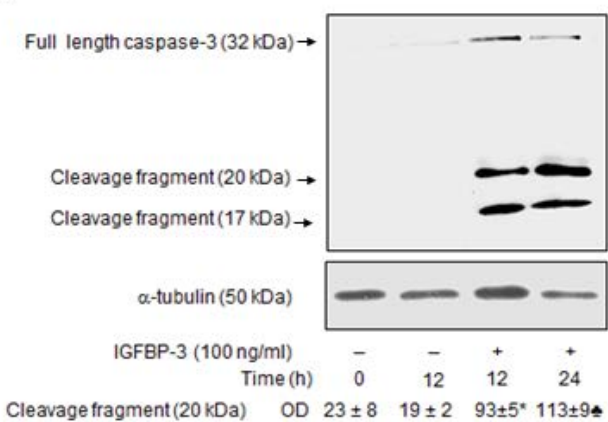

Figure 4: (A) Effects of IGFBP-3 and/or IGF-I on cell viability at different time points $(0,12,24 \mathrm{~h})$ after onset of cultures of Leydig cells isolated from 40-dayold rats. The numbers of viable cells were assessed employing the WST-1 procedure. Following treatment (see above), $10 \mu \mathrm{l}$ of the WST-1 reagent was added to each well (containing $1.5 \times 10^{4}$ cells); the incubation continued for an additional 60 minutes at $37^{\circ} \mathrm{C}$; and finally, the absorption of the culture medium at $450 \mathrm{~nm}$ was determined. $\mathrm{OD}=$ optical Density units. *: $\mathrm{p}<0.05$ compared to the specific time value for untreated control cells. (B) DNA fragmentation in Leydig cells isolated from 40-day-old rats. This measure of apoptosis was monitored in untreated cells at the beginning of the culture period $(0 \mathrm{~h})$ and in both treated and untreated cells following 48 hours of incubation ( $48 \mathrm{~h}$ ). Histone-associated DNA fragments in the cytoplasm of these cells were determined employing an ELISA procedure involving spectrophotometric quantitation at $450 \mathrm{~nm}(\mathrm{OD}$, optical density), *: $p<0.05$ compared to the 48 hour value for untreated control cells, $s: p<0.05$ compared to the 48 -hour value for cells exposed to $100 \mathrm{ng}$ IGFBP-3 per $\mathrm{ml}$ alone. (C) The figure depicts a representative Western blot, (including $\alpha$-tubulin as an internal contro for constant loading), of full-length caspase-3 and the activated cleavage fragments of this enzyme in Leydig cells isolated from the testis of 40-day-old rats (48h; see above) and cultured in the absence or presence of IGFBP-3. The OD values below represent densitometric quantitation of the active 20$\mathrm{kDa}$ cleavage fragment (means $\pm \mathrm{SD}$ for three independent experiments), *: $p<0.05$ compared to the initial value for untreated control cells, $\boldsymbol{s}: p<0.05$ compared to the $12 \mathrm{~h}$ value for IGFBP-3 $(100 \mathrm{ng} / \mathrm{ml})$.
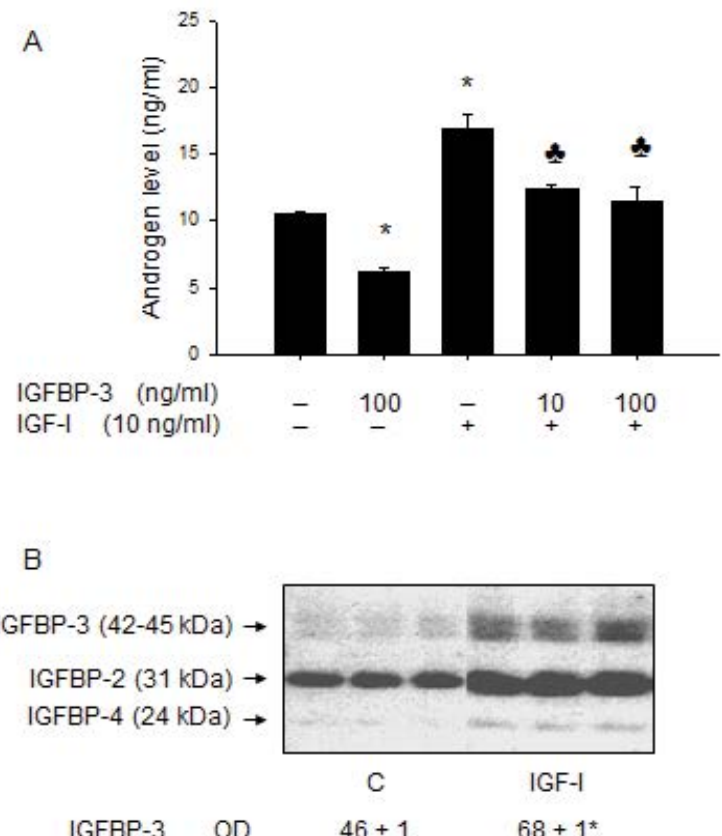

C

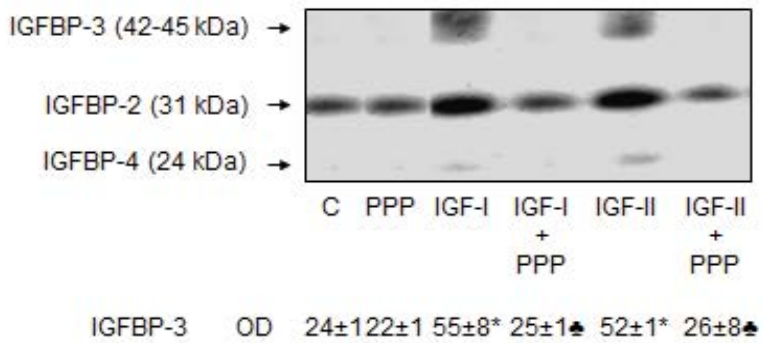

Figure 5: (A) Effects of IGFBP-3 and/or IGF-I on steroidogenesis in cultures of Leydig cells isolated from 40 -day-old rats. The Leydig cells $\left(7.5 \times 10^{6} \mathrm{cells} /\right.$ well $)$ were cultured and treated as described in the Materials and Methods, following which the culture media were collected for determination of the total level of

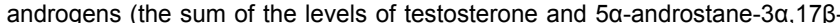
diol). The means $\pm S D$ for three independent experiments (each involving triplicate determinations) are shown, *: $p<0.05$ compared to the corresponding control values, $p<0.05$ compared to the corresponding value for cells treated with IGF-I alone. (B) Western ligand blotting of IGFBPs in the culture medium of Leydig cells isolated from 40-day-old rats and cultured in the presence or absence of IGF-I $(10 \mathrm{ng} / \mathrm{ml})$, radioactive IGF-I as the probe. The top figure depicts a representative blot and the OD values below the means \pm SD of this densitometric quantitation of IGFBP secretion in 3 independent experiments, *: $p<0.05$ compared to the corresponding control value. (C) Effects of PPP, a selective inhibitor of the IGF-IR, on the stimulation of IGFBP secretion by Leydig cells caused by IGF-I and IGF-II. Leydig cells $\left(2 \times 10^{6}\right.$ per well) rats were isolated, cultured and treated as described in the Materials and Methods. Subsequently, cultured medium was extracted and subjected to Western ligand blotting. The figure is a representative blot of Leydig cells and the OD values below the means $\pm S D, n=3$ of this densitometric quantification, *: $p<0.05$ compared to untreated cells, $s: p<0.05$ compared to the corresponding value for cells treated with IGF-I alone.

are under paracrine regulation by pro-inflammatory cytokines in the testis, linking inflammation to metabolic events, including regulation of steroidogenesis. Previous results from our group indicate that IL18 , which is produced constitutively by germ cells, may serve as a host 
A

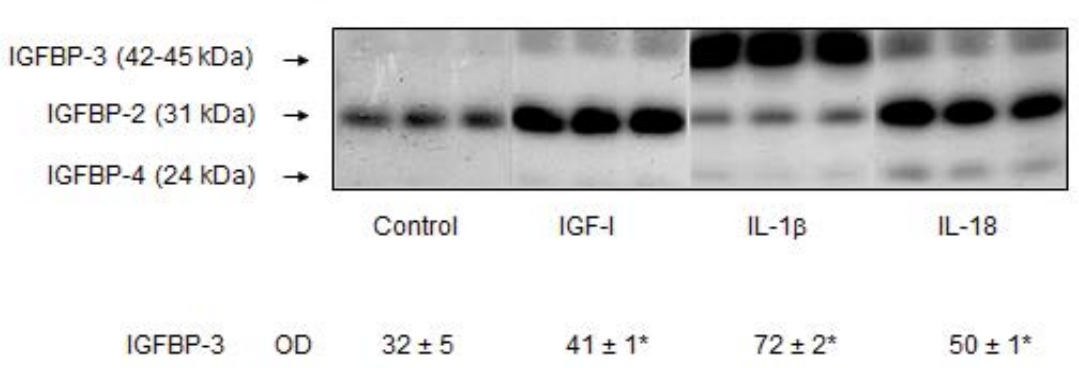

B

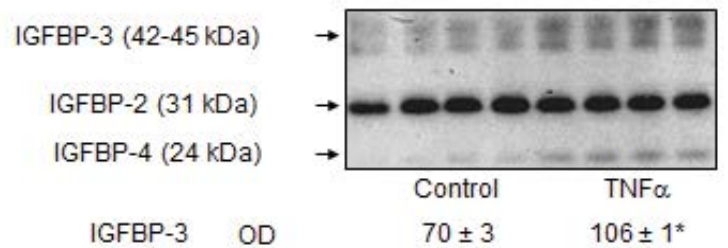

C

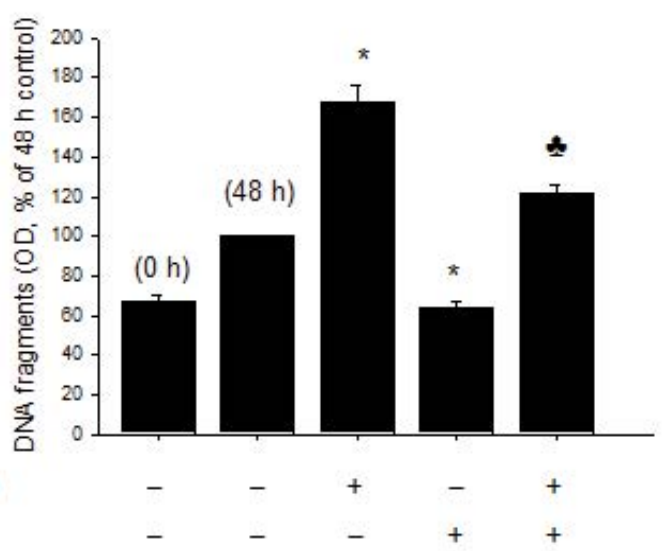

Figure 6: (A) Influence of IL-1b, IL-18 and IGF-I alone on the secretion of IGFBPs by Leydig cells isolated from 40-day-old rats. The cells were isolated, cultured $\left(2 \times 10^{6}\right.$ per well $)$ and treated as described in the Materials and Methods. The figures depicts representative Western ligand blots of extracts of the culture media, while the OD values below document the means \pm SD of the densitometric values obtained in three independent experiments, ${ }^{*}: p<0.05$ compared to untreated cells. (B) Effects of TNFa on the secretion of binding proteins in Leydig cells from 40 -day-old rats. The cells isolated were cultured $\left(2 \times 10^{6}\right.$ per well) and treated as described in the Materials and Methods. Representative Western ligand blotting of extracts of culture media, while the OD values underneath document the means $\pm S D$ of the densitometric values, $n=4$ of densitometric quantitation of these blots, ${ }^{*}: p<0.05$ compared to the untreated cells (48 h). (C) Effects of TNFa on apoptosis in Leydig cells from 40-day-old rats. Apoptosis in untreated Leydig cells at the beginning of the culture period (0h) and in both treated and untreated cells following 48 hours of incubation $(48 \mathrm{~h})$. The cytoplasmic levels of histone-associated DNA fragments in these cells were determined by an ELISA procedure involving spectrophotometric quantitation at $450 \mathrm{~nm}$. * $\mathrm{p}<0.05$ compared to the $48 \mathrm{~h}$ value for untreated control cells; $*$ : $p<0.05$ compared to TNFa treated cells.

defense factor in the male gonad [23]. Our present results indicate that IGFBPs modulate the function of this cytokine in the testis. IL-18, also produced constitutively by the rat testis [44], and IL- $1 \beta$ increase the secretion of IGFBP-3 [21] indicating that they occupy common signaling pathways and suggesting a possible role of IGFBP-3 in certain inflammatory conditions.

In summary, we demonstrate here that IGFBP-3 is expressed in a developmentally regulated fashion in the testis, where it induces apoptosis in Leydig cells in a manner that is also dependent on the 
stage of their development. IGFBP-3 blocks the promotion of survival by IGF-I and the secretion of this binding protein is regulated by cytokines. We propose that IGFBPs may play an important role in the regulation of Leydig cell numbers and development in the testis and thus may affect the total capacity of androgen biosynthesis.

\section{References}

1. LeRoith D, Roberts CT Jr (2003) The insulin-like growth factor system and cancer. Cancer Lett 195:127-137.

2. Colon E, Strand ML, Carlsson-Skwirut C, Wahlgren A, Svechnikov KV, et al (2006) Anti-apoptotic factor humanin is expressed in the testis and prevents cell-death in leydig cells during the first wave of spermatogenesis. J Cell Physiol 208: 373-385.

3. Lin T, Wang D, Nagpal ML, Chang W (1994) Human chorionic gonadotropin decreases insulin-like growth factor-I gene transcription in rat Leydig cells. Endocrinology 134: 2142-2149.

4. LeRoith D, Werner H, Beitner-Johnson D, Roberts CT Jr (1995) Molecular and cellular aspects of the insulin-like growth factor I receptor. Endocr Rev 16: 143 163

5. LeRoith D, Werner H, Neuenschwander S, Kalebic T, Helman LJ (1995) The role of the insulin-like growth factor-I receptor in cancer. Ann N Y Acad Sci 766 402-408.

6. Cohen $P(2006)$ Insulin-like growth factor binding protein-3: insulin-like growth factor independence comes of age. Endocrinology 147: 2109-2111.

7. Rajah R, Valentinis B, Cohen $P$ (1997) Insulin-like growth factor (IGF)-binding protein-3 induces apoptosis and mediates the effects of transforming growth factor-beta1 on programmed cell death through a p53- and IGF-independent mechanism. J Biol Chem 272: 12181-12188.

8. Lin T, Haskell J, Vinson N, Terracio L (1986) Characterization of insulin and insulin-like growth factor I receptors of purified Leydig cells and their role in steroidogenesis in primary culture: a comparative study. Endocrinology 119 1641-1647.

9. Lin T, Wang D, Nagpal ML, Shimasaki S, Ling N (1993) Expression and regulation of insulin-like growth factor-binding protein-1, -2, -3, and -4 messenger ribonucleic acids in purified rat Leydig cells and their biological effects. Endocrinology 132: 1898-1904.

10. Zhou J, Bondy C (1993) Anatomy of the insulin-like growth factor system in the human testis. Fertil Steril 60: 897-904.

11. Smith EP, Dickson BA, Chernausek SD (1990) Insulin-like growth factor binding protein-3 secretion from cultured rat sertoli cells: dual regulation by follicle stimulating hormone and insulin-like growth factor-I. Endocrinology 127: 27442751.

12. Wang D, Nagpal ML, Shimasaki S, Ling N, Lin T (1995) Interleukin-1 induces insulin-like growth factor binding protein-3 gene expression and protein production by Leydig cells. Endocrinology 136: 4049-4055.

13. Neuvians TP, Gashaw I, Hasenfus A, Hacherhacker A, Winterhager E, et al. (2005) Differential expression of IGF components and insulin receptor isoforms in human seminoma versus normal testicular tissue. Neoplasia 7: 446-456.

14. Bernardi P, Petronilli V, Di Lisa F, Forte M (2001) A mitochondrial perspective on cell death. Trends Biochem Sci 26: 112-117.

15. Li P, Nijhawan D, Budihardjo I, Srinivasula SM, Ahmad M, et al. (1997) Cytochrome $c$ and dATP-dependent formation of Apaf-1/caspase-9 complex initiates an apoptotic protease cascade. Cell 91: 479-489.

16. Gross A, McDonnell JM, Korsmeyer SJ (1999) BCL-2 family members and the mitochondria in apoptosis. Genes Dev 13: 1899-18911.

17. Ashkenazi A, Dixit VM (1998) Death receptors: signaling and modulation Science 281: 1305-1308

18. Beg AA, Baltimore D (1996) An essential role for NF-kappaB in preventing TNFalpha-induced cell death. Science 274: 782-784

19. Liu B, Lee KW, Anzo M, Zhang B, Zi X, et al. (2006) Insulin-like growth factorbinding protein-3 inhibition of prostate cancer growth involves suppression of angiogenesis. Oncogene.

20. Oh Y, Muller HL, Pham H, Rosenfeld RG (1993) Demonstration of receptors for insulin-like growth factor binding protein-3 on Hs578T human breast cancer cells. J Biol Chem 268: 26045-26048.

21. Colon E, Svechnikov KV, Carlsson-Skwirut C, Bang P, Soder O (2005) Stimulation of steroidogenesis in immature rat Leydig cells evoked by interleukin-1alpha is potentiated by growth hormone and insulin-like growth factors. Endocrinology 146: 221-230.

22. Lysiak JJ, Nguyen QA, Kirby JL, Turner TT (2003) Ischemia-reperfusion of the murine testis stimulates the expression of proinflammatory cytokines and activation of c-jun $\mathrm{N}$-terminal kinase in a pathway to $\mathrm{E}$-selectin expression. Biol Reprod 69: 202-210

23. Strand ML, Wahlgren A, Svechnikov K, Zetterstrom C, Setchell BP, et al. (2005) Interleukin-18 is expressed in rat testis and may promote germ cell growth. Mo Cell Endocrinol 240: 64-73.

24. Jonsson CK, Zetterstrom RH, Holst M, Parvinen M, Soder O (1999) Constitutive expression of interleukin-1alpha messenger ribonucleic acid in rat Sertoli cells is dependent upon interaction with germ cells. Endocrinology 140: 3755-3761.

25. Wang G, Hardy MP (2004) Development of leydig cells in the insulin-like growth factor-I (igf-I) knockout mouse: effects of igf-I replacement and gonadotropic stimulation. Biol Reprod 70: 632-639.

26. Moore A, Chen CL, Davis JR, Morris ID (1993) Insulin-like growth factor-I mRNA expression in the interstitial cells of the rat testis. J Mol Endocrinol 11: 319-324.

27. Vasilcanu D, Girnita A, Girnita L, Vasilcanu R, Axelson M, et al. (2004) The cyclolignan PPP induces activation loop-specific inhibition of tyrosine phosphorylation of the insulin-like growth factor-1 receptor. Link to the phosphatidyl inositol-3 kinase/Akt apoptotic pathway. Oncogene 23: 7854 7862.

28. Klinefelter GR, Hall PF, Ewing LL (1987) Effect of luteinizing hormone deprivation in situ on steroidogenesis of rat Leydig cells purified by a multistep procedure. Biol Reprod 36: 769-783.

29. Svechnikov KV, Sultana T, Soder O (2001) Age-dependent stimulation of Leydig cell steroidogenesis by interleukin-1 isoforms. Mol Cell Endocrinol 182 : 193-201.

30. Khan SA, Khan SJ, Dorrington JH (1992) Interleukin-1 stimulates deoxyribonucleic acid synthesis in immature rat Leydig cells in vitro. Endocrinology 131: 1853-1857.

31. Payne AH, Downing JR, Wong KL (1980) Luteinizing hormone receptors and testosterone synthesis in two distinct populations of Leydig cells. Endocrinology 106: $1424-1429$

32. Wang GM, Ge RS, Latif SA, Morris DJ, Hardy MP (2002) Expression of 11 betahydroxylase in rat Leydig cells. Endocrinology 143: 621-626.

33. Petersen C, Boitani C, Froysa B, Soder O (2001) Transforming growth factoralpha stimulates proliferation of rat Sertoli cells. Mol Cell Endocrinol 181: 221 227

34. Schlatt S, de Kretser DM, Hedger MP (1999) Mitosis of resident macrophages in the adult rat testis. J Reprod Fertil 116: 223-228.

35. Colon E, Zaman F, Axelson M, Larsson O, Carlsson-Skwirut C, et al. (2007) Insulin-like growth factor-I is an important antiapoptotic factor for rat leydig cells during postnatal development. Endocrinology 148: 128-139.

36. Hossenlopp P, Seurin D, Segovia-Quinson B, Hardouin S, Binoux M (1986) Analysis of serum insulin-like growth factor binding proteins using western blotting: use of the method for titration of the binding proteins and competitive binding studies. Anal Biochem 154: 138-143.

37. Buckbinder L, Talbott R, Velasco-Miguel S, Takenaka I, Faha B, et al. (1995) Induction of the growth inhibitor IGF-binding protein 3 by p53. Nature $377: 646-$ 649

38. Butt AJ, Fraley KA, Firth SM, Baxter RC (2002) IGF-binding protein-3-induced growth inhibition and apoptosis do not require cell surface binding and nuclear translocation in human breast cancer cells. Endocrinology 143: 2693-2699.

39. Butt AJ, Firth SM, King MA, Baxter RC (2000) Insulin-like growth factorbinding protein-3 modulates expression of $\mathrm{Bax}$ and $\mathrm{Bcl}-2$ and potentiates p53independent radiation-induced apoptosis in human breast cancer cells. J Bio Chem 275: 39174-39181

40. Ge RS, Dong Q, Sottas CM, Chen H, Zirkin BR, et al. (2005) Gene expression in rat leydig cells during development from the progenitor to adult stage: a cluster analysis. Biol Reprod 72: 1405-1415. 
Citation: Colón E, Skwirut CC, Svechnikov KV, Söder O (2016) Autocrine/Paracrine Insulin-like Growth Factor Binding Protein-3 Acts as Pro-apoptotic Factor for Leydig cells in the Rat Testis. J Steroids Horm Sci 7: 174. doi:10.4172/2157-7536.1000174

Page 10 of 10

41. Kenchappa P, Yadav A, Singh G, Nandana S, Banerjee K (2004) Rescue of TNFalpha-inhibited neuronal cells by IGF-1 involves Akt and c-Jun N-terminal kinases. J Neurosci Res 76: 466-474.

42. Wang JY, Grabacka M, Marcinkiewicz C, Staniszewska I, Peruzzi F, et al. (2006) Involvement of alpha1beta1 integrin in insulin-like growth factor-1mediated protection of PC12 neuronal processes from tumor necrosis factoralpha-induced injury. J Neurosci Res 83: 7-18.

43. Besset V, Le Magueresse-Battistoni B, Collette J, Benahmed M (1996) Tumor necrosis factor alpha stimulates insulin-like growth factor binding protein 3 expression in cultured porcine Sertoli cells. Endocrinology 137: 296-303.

44. Wahab-Wahlgren A, Holst M, Ayele D, Sultana T, Parvinen M, et al. (2000) Constitutive production of interleukin-1alpha mRNA and protein in the developing rat testis. Int J Androl 23: 360-365. 